\title{
MEDIA LITERACY, JOURNALIST AND EMPOWERMENT OF DEMOCRACY
}

\author{
Neeraj Khattri (a) \\ (a) Institute of Media Studies Shri Ramswaroop Memorial University, Village Hadauri, Post Tindola, \\ Lucknow - Deva Road, Barabanki, Uttar Pradesh 225003, India. \\ E-mail: neerajkhattri101@gmail.com
}

\begin{abstract}
In a democracy like India media has established many epitomes with its working style. These epitomes are helping media in becoming the fourth pillar. It has been seen that the journalists working in media had to face many problems during the establishment of these epitomes. These problems were related to their internal development, social problems and their understanding of the same. This research paper has been written keeping these problems in mind. Journalists working in Jaipur were interviewed for knowing their problems. This research paper has tried to investigate how a journalist works during making of content and its analysis, how well he/she understands the social problems and kind of understanding he/she has to calculate and evaluate the risk.

It was found that media literacy among journalists was left unattended to. Author states that journalists of Jaipur are not yet familiar with media related understanding, media analysis and modern media and about $78 \%$ of them adopt information furnished by unreliable and uncertified sources while using social media.

The researcher has tried to underline the importance of media literacy for journalists through this research paper. This research paper recommends taking media literacy to Journalists.
\end{abstract}

\section{Keywords}

Media Literacy, Democracy, Journalist, Content, Model, Interview, Empowerment, Mass Media, Media organization, Media Research

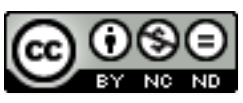

This work is licensed under a Creative Commons Attribution-NonCommercialNoDerivatives 4.0 International License 


\section{INTRODUCTION}

A nation's democratic structure can reap fruits only when all its citizens are literate. Today's age of modern communication has changed the meaning of 'being literate'. Being able to read and write is not enough. One has to be a step forward and be aware and literate about all that is happening around him/her. This literacy is more complex than the basic education imparted to people. Health related education, gender related education, economy related education, E-literacy and media related literacy are prime examples of such literacy and play an important role in establishing a person in this modern society (Nielsen, 2011).

Today only $74 \%$ of India's population is literate, therefore India is still to achieve a lot in this field. This literacy doesn't include the literacy mentioned above. This literacy rate implies that $74 \%$ of our population can read and write. The effectiveness and strength of a nation's democracy depend upon the intelligence and literacy of its people. The intelligence of people has a direct bearing of the effectiveness of a democracy. A democracy is said to be good when even the weakest sections of society enjoy the same rights that the strong sections enjoy (Khattri, 2013).

India is the largest democracy in the world, yet it can't be called a forceful democracy. This is because the under developed sections of society have still not been connected to the main stream. One of the major reasons for this is that though people can read and write, they are not literate. The researcher has tried to investigate the media related literacy of journalists through this research paper. This research paper has tried to investigate how a journalist works during making of content and its analysis, how well he/she understands the social problems and kind of understanding he/she has to calculate and evaluate the risk.

During the research the researcher found that just pursuing a course journalism and mass-communication doesn't make a person a literate journalist. After having done this course a person gets familiar with a few things and softwares related to this subject but this is not enough to make him/her media literate.

Many problems inspired the researcher to undertake this research. The first problem is that India is not doing enough to promote media literacy among journalists. Secondly, after conversations with journalists of Jaipur it was found that they are not yet familiar with media related understanding, media analysis and modern media. The understanding of media and working style of many media-persons working in various print media institutions in Jaipur was found to be questionable. Work is required 
to be done in this direction. This research paper is an attempt in this direction.

Journalist are the first teachers of this society as the news written by them I newspapers reaches every doorstep. Our society reads it to get informed, become knowledgeable and proactive. These aspects get weakened if the journalists themselves lack understanding of the subject and analytical power which in turn weakens all three pillars of our democracy. In order to restore the rigidity of the three pillars of democracy it is necessary to reinforce the well-known fourth pillar of democracy, the news community. Its each unit needs to be made literate and strong (Baker, 2012).

This research paper is an attempt to understand the problems faced by a journalist during his/her internal development and the way the journalist understands the related social problems and insecurities, the ways of getting rid of them, and the strategies which need to be employed. Therefore it can be said that in order to strengthen our society this research is vital and necessary.

The socio-economic culture of various media houses in Jaipur has been studied in this research paper. In addition to this, ways of strengthening media in order to strengthen our democracy have been sought.

Following are the objectives of this research paper:

1) To know their working style and work period.

2) To know the problems faced by them in their field related internal development

3) Enabling them to develop an understanding of and strategies regarding working style, internal development and social problems faced by them.

4) To know if the journalists understand their security related issues..

\section{MATERIAL AND METHOD}

The process of journalists working on their understanding of journalism and becoming literate is complex. This research is based on about four hundred salary earning journalist who work in Jaipur. Forty of them were interviewed and answers to the above mentioned questions were sought from them. The figures collected were statistically analysed. The facts collected have been duly presented in this research paper (Kothari, 2004). 


\section{RESULT AND DISCUSSION}

The interviews revealed many facts which related not only to their internal development, working style, but also their socio economic culture. It was realised that about $62 \%$ of journalists in Jaipur don't use any new medium for enhancement of their own knowledge. They still rely on old knowledge funds to develop internally.

About $78 \%$ of them adopt information furnished by unreliable and uncertified sources while using social media. It was tried to find out how their working style effects their internal development. These journalists still believe in traditional practices of journalism. Social media is just a means of entertainment for them whereas mobile phones are used a direct means of journalism in regions like the Scandinavian region of Europe.

Sheri Top Clover, who is an assistant professor in the media studies department of Temple University and is also the director of centre for media and information literary, has presented her views on media literacy. She has been the president of national association for media literacy education. Through her research she has shown that though America has developed a lot in media education but a lot can still be done in the field of media literacy. In India also, the central government has directed all the central universities to work in the direction of media literacy, but no explicit course in this regard can be seen in the curriculum (NAMLE, n.d.).

The entire journalists undertake a course in journalism before taking up this profession, but it is the lack of media literacy which jeopardizes their growth. Many of them have admitted that for them media literacy is the same as the education they have been provided during their course. As stated before, even today the working style of journalists working for Hindi newspapers follow traditional ways of reporting, writing and editing (Kubey, 2004).

It was found in the research that their selection of working style itself is a matter of concern, and actions need to be taken. India is an unsafe for journalists. America's committee communal to protect journalists has claimed that India as unsafe a place for journalists as the likes of Nigeria, Ethiopia, Pakistan and Mexico (Stein \& Prewett, 2009).

It was found that Indian journalists have been divided into two sections. First of those who report in accordance with what their central and state governments want them to report and believe in keeping them happy in whatever way possible. The others are the journalists who don't let anything come in between them and responsible journalism and even force the government to be answerable to the people of this democracy depicting the power of pen and paper. These journalists spell trouble for the 
government and the corrupt people supported by it. As the journalists in India don't receive any special protection, they can easily be subjected to their wrath and anguish. It has been found in this research that $74 \%$ of journalists in Jaipur don't have any special knowledge and understanding about their safety and code of conduct.

\section{CONCLUSION}

As stated in the beginning, this research is the need of the hour. This has been proved after this research. This research sought to know the problems faced by Hindi media journalists in their development, working style and security and also ways to do away with these problems.

It was found that journalists have to face some very basic problems during their internal development. They are also not privy to the technological advancements, this hampers their journalism and working style. They are not able to fully utilise facilities like mobile phones, internet, social media for the betterment of their journalism. If they incorporate the use of these mediums in their journalism, Jaipur's largely stereo type journalism would become modern.Jaipur's journalists need to change the way they lead their lives in order to change their working style.

Security is a person's fundamental right, and security of journalists is of paramount importance for strengthening our democracy. Eight Journalists were murdered in 2016, and several journalists were troubled, scared and tortured for their fearless journalism. At times even the government tried to pressurise/influence them and to stop them from dispensing their duties by means of legal charges and other impositions. These are not good signs for a democracy.

The researcher has concluded that both legislature and judiciary need to work for the safety of journalists so that they can work fearlessly.

\section{RECOMMENDATION}

It won't be an over statement if one says that media literacy is not even born yet in India. Western regions like Europe, America and Latin America have seen researches being carried out in this field for the last 40 years. Indian government and various education agencies must realise the importance of media literacy and fabricate it into our system. Through this research the researcher recommends the following:

1) The government and the education ministry must conduct a research on various media schools and organisations to understand the extent of media literacy among journalists. 
2) The central and state governments must pass laws to inculcate media literacy in their university curriculums.

3) Indian government must form a commission to understand the need of media literacy, related challenges and to fabricate a fitting curriculum.

4) University grant commission must train teachers of journalism and journalists in the field of media literacy as a part of its human resources development programme.

5) Government and non governmentorganisations must be provided funds for research in the field of media literacy.

6) Government and media organisations of Jaipur must seek training from foreign journalists.

7) Government must inculcate this subject in school curriculum for media personnel, media policy makers and media subscribers to create an atmosphere for promotion of media literacy.

8) Conferences and seminars on media literacy must be held in media institutions not only in Jaipur but also in other parts of India.

9) The education policy makers of India must form a top class organisation to promote media literacy, understand the challenges involved, formulate strategies to counter the difficulties and popularise media literacy.

\section{References}

Baker, W. F. (2012). Media Literacy in the K12 classroom. International Society for Technology in Education.

Khattri, N. (2013). Interactive Media and Society. New Delhi: Kalpaz Publication.

Kothari, C. R. (2004). Research Methodology: Methods and Techniques. 2nd Edition. New Delhi: New Age International Publishers.

Kubey, R. (2004). Media Literacy and the Teaching of Civics and Social Studies at the Dawn of the 21st Century. American Behavioral Scientist, 48(1), 69-77 https://doi.org/10.1177/0002764204267252.

NAMLE. (n.d.). Retrieved from National Association for Media Literary Education: https://namle.net/

Nielsen, G. (2011, March). Media Literacy in the Social Studies Classroom. Education Digest: Essential Readings Condensed for Quick Review, 76(7), 43-45.

Stein, L., \& Prewett, A. (2009). Media Literacy Education in the Social Studies: Teacher Perceptions and Curricular Challenges. Teacher Education Quarterly, 36(1), 131-148. 


\title{
МЕДИАГРАМОТНОСТЬ, ЖУРНАЛИСТИКА И РАЗВИТИЕ ДЕМОКРАТИИ
}

\author{
Кхаттри Нираж (a) \\ (а) Институт медиаисследований, Мемориальный университет Шри Рамсваруп, Деревня Хадаури, \\ Пост Тиндола, Лакхнау - Дева Роуд, Барабанки, Уттар Прадеш 225003, Индия. \\ E-mail: neerajkhattri101@gmail.com
}

\section{Аннотация}

В демократических странах, подобных Индии, СМИ создали множество моделей со своим стилем работы. Это дало возможность СМИ стать четвертой ветвью власти. Опыт показал, что журналисты, работающие в средствах массовой информации, сталкивались с множеством проблем при создании подобных моделей. Эти проблемы берут свое начало в их внутреннем развитии, социальных проблемах и осознании всего этого. Эта статья была написана на основании опроса работающих в Джайпуре журналистов, направленного на выяснение имеющихся у них проблем. В исследовании была предпринята попытка проследить, как журналист работает во время создания контента и его анализа, насколько хорошо он понимает социальные проблемы и как рассчитываются и оцениваются риски. Автор отмечает, что медиаграмотность не является вопросом, волнующим журналистов. По мнению автора, журналисты из Джайпура пока еще не знакомы с особенностями средств массовой информации, анализом СМИ и современными средствами массовой информации, и около $78 \%$ из них опираются в своей работе на информацию, предоставленную ненадежными и несертифицированными источниками, при использовании социальных сетей.

Автор в своей статье попытался подчеркнуть важность медиаграмотности для работы журналистов. В данном исследовании автор считает, что необходимо распространять медиаграмотность среди журналистов.

\section{Ключевые слова}

Медиа Грамотность, Демократия, Журналист, Контент, Модель, Интервью, Расширение прав и возможностей, Средства массовой информации, Организация СМИ, Исследования СМИ

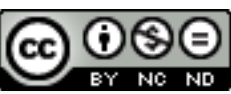

This work is licensed under a Creative Commons Attribution-NonCommercialNoDerivatives 4.0 International License 


\section{Список литературы}

Baker, W. F. (2012). Media Literacy in the K12 classroom. International Society for Technology in Education.

Khattri, N. (2013). Interactive Media and Society. New Delhi: Kalpaz Publication.

Kothari, C. R. (2004). Research Methodology: Methods and Techniques. 2nd Edition. New Delhi: New Age International Publishers.

Kubey, R. (2004). Media Literacy and the Teaching of Civics and Social Studies at the Dawn of the 21st Century. American Behavioral Scientist, 48(1), 69-77 https://doi.org/10.1177/0002764204267252.

NAMLE. (n.d.). Retrieved from National Association for Media Literary Education: https://namle.net/

Nielsen, G. (2011, March). Media Literacy in the Social Studies Classroom. Education Digest: Essential Readings Condensed for Quick Review, 76(7), 43-45.

Stein, L., \& Prewett, A. (2009). Media Literacy Education in the Social Studies: Teacher Perceptions and Curricular Challenges. Teacher Education Quarterly, 36(1), 131-148. 